\title{
RESEARCHING PRACTICE AND COLLABORATION AS A MEANS TO PROMOTE INQUIRY IN SCIENCE TEACHING
}

\author{
Monica Baptista \\ University of Lisbon, Portugal \\ E-mail: mbaptista@ie.ul.pt
}

\begin{abstract}
We live in a very complex and ever changing society, which requires from its citizens a continuous involvement in decision-making and continuous learning. The issues that were exclusive experts' responsibility today are brought to public, thus requiring the society active participation. Hence it is crucial that each citizen is informed, in order to be critical and adopt an intervening and sustained stance. Therefore, improving scientific literacy is a current concern of our times, considering the overall contradictory scenario. On the whole, it is recognized that fully participating in today's society requires an understanding of science and scientific activity. Nevertheless, several studies show that scientific literacy levels, within the general population and among students, are not as high as would be expectable. So, to improve students' scientific literacy levels is the main goal of science education research. But what learning situations can be created to improve students' scientific literacy? Recently, a number of studies pointed out inquiry as one possible learning situation. But then the main question is: why inquiry? Inquiry emphasizes the development of scientific and procedural knowledge, as well as other relevant competencies (e. g. reasoning, communication and attitudes) and puts students in the centre of their learning. It engages students in different situations, namely in identifying problems, formulating hypotheses, researching in books and other sources of information, planning investigations, collecting and interpreting data, reviewing what they know about the experience, connecting explanations to scientific knowledge, reporting results, arguing with basis on evidences, and communicating (NRC, 2000) - all crucial competencies to foster scientific literacy.

Nevertheless, several obstacles are faced by teachers when they try to put inquiry into action, as it requires not only a break in their routines (i.e., changes in their traditional teaching practices), as well as in their teachings' conceptions. Breaking routines is never easy because most teachers are comfortable with teacher-centered teaching. So that teachers will become actively involved in the process of change, they need to acquire new knowledge, skills and dispositions, and to feel competent and comfortable when putting inquiry into practice. But for such a change to occur, teachers must feel motivated and willing to change their practices, and they must feel free to discuss the problems that arise when implementing inquiry, which are completely different from their usual ones. This is a complex and difficult process, which raises many challenges to teachers and science educators. So, what can we do? What are the possible ways? From my point of view, there are two crucial ways to support changes: (i) teachers as researchers of their own practice; (2) collaborative work among teachers. Why is it important for teachers to be researchers of their own practice? Some studies show that teachers reflect on issues that do not let them challenge their practices. Thus, to study their practice may be an opportunity to be reflective about their own performances and to consider other options. By choosing to take a researcher's role, teachers get a deeper understanding of their practice and an opportunity to build knowledge from it. To research their own practice is a powerful means for teachers to learn about their students and about the impact of teaching in their learning processes. Finally, when teachers study their practice, they are experiencing a similar process
\end{abstract}


Monica BAPTISTA. Researching Practice and Collaboration as a Means to Promote Inquiry in Science Teaching

PROBLEMS

OF EDUCATION

IN THE $21^{\text {st }}$ CENTURY Volume 59, 2014

to the inquiry when they formulate a problem, mobilize theoretical ideas, develop a research plan, collect and interpret data, report results and communicate and reflect about it. As pointed by Chapman (2013), teachers have more opportunity to develop an understanding of inquiry "if they learn through inquiry" and more highly "it is important for them to learn in a way that will help them to develop an inquiry stance as a central aspect of being a teacher" (p. 129).

Another important question is: why do teachers need collaboration? More and more, having been given the challenges of the present school, it is important for teachers to develop collaborative work. Collaboration is a crucial strategy to overcome daily problems, as it allows teachers to increase their confidence and it leads them to new experiences. Collaborative work allows to acquiring new learning and solving problems that teachers face daily. Through verbalization and interaction, teachers formulate ideas, learn from each other, interiorize theory, criticize their conceptions and those of others, increase their knowledge and discuss new strategies for teaching and learning. Moreover, collaborating with the specific purpose of leading a group of teachers doing research on their own practice, it is essential to strengthen the determination to act, overcome fears and face dilemmas, and to create a repository of experiences, skills and perspectives that allow them to extend the possibility of questioning and understanding. Thus, the connection between collaboration and teachers' researching their own practice is a means to promote inquiry in science teaching.

\section{References}

Chapman, O. (2013). Mathematics teachers' learning through inquiry. Sisyphus - Journal of Education, 1 (3), 122-150.

National Research Council - NRC (2000). Inquiry and the national science education standards. Washington, DC: National Academy.

Received: April 12, 2014

Accepted: April 15, 2014

Monica Baptista $\quad$ PhD., Assistant Professor, University of Lisbon, Portugal.

E-mail: mbaptista@ie.ul.pt

Website: http://www.ie.ul.pt/portal/page?_pageid=406,1303580\&_dad=portal\&_ schema=PORTAL 